
\title{
B Reserarch Sulure \\ Increased MMP2 contributes to the diagnosis and prognosis of lung cancer
}

\author{
Liping Han \\ Jining Medical University \\ Baowei Sheng \\ Jining Medical University \\ Qingdi Zeng \\ Jining Medical University

\section{Wei Yao} \\ Zoucheng Kanzhuang Township Health Center

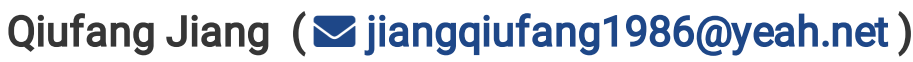 \\ Jining Medical University
}

\section{Research article}

Keywords: Lung cancer, matrix metalloproteinase 2, MMP2, serum, diagnosis, prognosis

Posted Date: January 13th, 2020

DOI: https://doi.org/10.21203/rs.2.20737/v1

License: (c) (1) This work is licensed under a Creative Commons Attribution 4.0 International License. Read Full License 


\section{Abstract}

Background: Matrix metalloproteinase 2 (MMP2) has been found to be correlated with the occurrence and development of lung cancer; the aim of this study was to investigate the clinical significance and prognosis value of MMP2 expression in lung cancer.

Methods: The expression of MMP2 in lung cancer tissues was tested by immunohistochemistry and its serum level was tested by enzyme-linked immunosorbent assay.

Results: The expression of MMP2 was higher in lung cancer tissues and serum of lung cancer patients, and increased MMP2 was associated with tumor size, lymph node metastasis, advanced stage and postoperative survival time $(\mathrm{p}<0.05)$. The sensitivity and specificity of serum MMP2 for distinguishing lung cancer from lung benign diseases were $96.51 \%$ and $65.85 \%$; and for distinguishing lung cancer from normal individuals were $97.67 \%$ and $75 \%$.

Conclusions: Increased serum MMP2 could be considered as a potential molecular biomarker for diagnosis and prognosis of lung cancer.

\section{Introduction}

Lung cancer has become one of the world's major diseases that threaten human health. Especially in China, due to air pollution and environmental degradation, its morbidity and mortality are increasing year by year [1]. Lung cancer is a multi-step process involving genetic and epigenetic changes, study shows that external factors and internal factors will result in DNA damage, and ultimately lead to normal lung epithelial cells into lung cancer cells [2]. Lung cancer is divided into two broad histologic classes, which grow and spread differently: small-cell lung carcinomas (SCLC) and non-small cell lung carcinomas (NSCLC) [3]. Approximately $80 \%$ of lung cancers are grouped as NSCLC, which are clinically and pathologically different from SCLC [4]. There are a considerable number of genomic aberrations in NSCLC serving as potential predictive biomarkers and drug targets and still more, such as epidermal growth factor receptor (EGFR) mutations and the development of specific EGFR tyrosine kinase inhibitors [5]. Now, the findings of abnormal molecule, gene mutation, and genetic phenotype have been suggested to improve the diagnostic accuracy of lung cancer at the early stage [6].

Matrix metalloproteinases (MMPs) are proteolytic enzymes that play a major role in extracellular matrix (ECM) remodeling but have also been shown to be involved in the regulation of multiple stages of cancer progression including cell growth, differentiation, apoptosis, migration, invasion and immune surveillance [7]. Matrix metalloproteinase 2 (MMP2) is capable of degrading the majority of components of the extracellular matrix. It is widely believed that the effect of MMP2 on the extracellular matrix is closely associated with tumor invasion and metastasis [8]. The gene encoding MMP2 is located on human chromosome 16q21 and consists of 13 exons and 12 introns, with a total length of the structural gene is $27 \mathrm{~kb}$ [9]. MMP2 expression has been found to be increased in a variety of cancers and high expression of MMP2 can potentially promote cell proliferation, motility and metastasis of malignant tumors [10-14]. 
Moreover, many target-specific anti-MMP2 investigations have shown that down-regulation of MMP2 reduces cell proliferation, clonal growth, motility and metastasis of malignant tumors; and anti-MMP2 effect increases apoptosis of malignant tumors [15-17]. However, study concerning its expression in serum of lung cancer patients is scarce. In this study, we tested the expression level of the MMP2 protein in tissues and serum of lung cancer patients and evaluated the clinical significance and prognosis value of MMP2 expression to lung cancer.

\section{Methods}

\section{Patients}

From January 2010 to December 2012, 65 patients were diagnosed with lung cancer and underwent lung cancer resection at the Jining N0.1 People's Hospital, Jining, China. We collected lung cancer tissues of these patients for a retrospective study. We also cut their matching adjacent non-malignant tissues from the edge of the tumor block at least $3 \mathrm{~cm}$ as a normal control. From January 2016 to January 2017, the blood samples of 86 patients with lung cancer, and 41 of patients with benign lung disease (from lung reduction surgery, inflammatory pseudotumor and pulmonary trauma resection) and 60 healthy peoples (receiving strict physical examination) were gathered from the same hospitals mentioned above for serological testing. All patients were not received radio/chemotherapy before collecting specimens. The clinicopathological data of patients were listed in Table 1. All samples were collected in accordance with the ethical guidelines, written informed consent was received. All patients were approached based on approved ethical guidelines, and those who agreed to participate in this study were required to sign consent forms. All the patients signed the informed consent before including the study. The study was approved by Research Ethics Committee of Jining NO.1 People's Hospital, Jining, China. We confirmed that all methods were performed in accordance with the relevant guidelines and regulations.

\section{Tissue Microarray (TMA) construction}

A tissue array instrument was employed to construct the tissue microarray (TMA) (Beecher Instruments, Manual Tissue Arrayer, USA). We screened representative tumor areas (avoiding necrotic tissues and noncancerous tissues) on donor wax blocks. We perforated the tissue of the labeled donor tissue and collected $2 \mathrm{~mm}$ of tissue core, and placed the collected tissue core in the small hole of the recipient wax mass (almost the same diameter as the tissue core). So repeatedly, we put all the tissue cores according to the order of design. Then, we dehydrated and fixed the TMA block and cut slices with a thickness of $4.5 \mu \mathrm{m}$. Finally, the tissue slices were attached to poly-lysine-treated slides, which were stored at $-4^{\circ} \mathrm{C}$ after drying. 
The numbering of blood samples was recorded and the specimen collection containers were labeled according to the numbering. We collected blood samples from the elbow vein of patients. The blood samples were shaken and mixed immediately. We separated the serum from the blood out as soon as possible. Specifically, we centrifuged the blood at $3000 \mathrm{rpm}$ for 10 minutes and collected the serum, then the serum was stored at $-20^{\circ} \mathrm{C}$ under freezing conditions. The frozen serum was thawed at room temperature when testing them.

\section{Immunohistochemistry (IHC)}

The expression level of MMP2 was determined using SABC IHC techniques (SA1094, Bostere Biotech Company, Wuhan, China) according to the introduction of kit. A rabbit anti-human MMP2 monoclonal antibody (BA3716; 1:50 dilution; Bostere Biotech Company, Wuhan, China) was used as the first antibody. The slices of positive staining provided by the antibody kit were served as the positive control and the phosphate buffer saline (PBS) in stead of the first antibody was used as the negative control. Staining intensity and staining area were two semi-quantitative indicators of MMP2 staining. Immunostaining was blindly assessed according to previously published scoring methods [18]. The staining intensity includes the following levels: 0 , no staining; 1 , mild staining; 2 , moderate staining; 3 , intense staining. The score for the staining area is as follows: 0 , no staining in any fields; $1,<30 \%$ of staining area, 2 , between $30 \%$ and $60 \%$ staining area; $3,>60 \%$ staining area. A combined staining score (intensity + area) of $\leq 2$ was defined as low expression, between 3 and 4 as moderate, and between 5 and 6 was considered as high expression [18].

\section{Enzyme-linked immunosorbent assay (ELISA)}

The serum level of MMP2 was measured by ELISA kit (Bostere Biotech Company, Wuhan, China) strictly following the protocol designed by the producer. Firstly, we determined the number of wells that have been coated with the antibody to be tested, and No. 1 well was defined as a blank coloring hole. We took $0.1 \mathrm{ml}$ of different concentrations of standard sample adding on a row of 7 wells, but the No. 1 well only added the sample dilution. The plate was added with a lid and reacted at $37^{\circ} \mathrm{C}$ for 10 minutes. After that, the liquid inside the plate was thrown. The anti-human MMP2 antibody working solution was added to the wells (except for blank coloring well), and reacted at $37^{\circ} \mathrm{C}$ again for 60 minutes. Then, the wells were washed 3 times with $0.01 \mathrm{M}$ PBS, and the avidin-biotin-peroxidasecomplex (ABC) working solution was added to the wells (except for blank coloring well) at $37^{\circ} \mathrm{C}$ for 30 minutes. After washing the wells for 5 times with $0.01 \mathrm{M}$ PBS, a $90 \mu$ l of tetramethylbenzidine (TMB) coloring liquid was added to each well at $37^{\circ} \mathrm{C}$ with a dark condition for 25 minutes. Finally, $0.1 \mathrm{~mL}$ of the stop solution was added to each well to terminate the reaction, and the color intensity was measured at a wavelength of $450 \mathrm{~nm}$ using a photometer. The standard curve was plotted based on the concentration of the standard sample and the optical density of each well. 
Statistical analysis

The relationship between the expression of MMP2 in tissues and clinicopathological parameters was analyzed by the Chi-square test, McNemar test and Fisher's exact test. The serum test data of MMP2 belonged to the continuous variables and thus was assessed by Student's $t$-test, Kruskal-Wallis test and One-way ANOVA. The definition of patient's survival is from the date of the operation to the date of death (the death of any cause) or the last known date of the patient's life (loss of visit). The survival curve was drawn according to kaplan-meier method and the logarithmic rank test was used to determine whether the expression of MMP2 affect the survival of patients. A Cox-proportional risk regression model with multivariate analysis was employed to test the mixed effect of variables with the most closely correlated expression levels of MMP2. The cutoff values of serum MMP2 for discriminating lung cancer from benign lung diseases and normal individuals were determined by receiver operating characteristic (ROC) curve analysis. All tests were two-sided. A statistical significance was that the P value was less than 0.05 . The statistical analysis were performed by the SPSS 19.0 software [19].

\section{Results}

The expression of MMP2 in lung cancer tissues was higher than that in adjacent normal tissues

In IHC analysis, MMP2 was mainly expressed in cytoplasm and membrane of lung cancer cells and normal cells, showing yellow and brown (Figures 1A-F). Statistical analysis showed that high expression rate of MMP2 reached $37 \%$ (24/65) in lung cancer tissues, whereas only accounted for $13 \%(20 / 65)$ in the adjacent non-malignant tissues, which suggested that the expression of MMP2 in lung cancer tissues was higher than that in adjacent normal tissues $(p=0.002)$ (Table 2, Figure 2A).

Highly expressed MMP2 was associated with differentiation, tumor size, lymph node metastasis and clinical stage of lung cancer

As shown in Table 2, the expression of MMP2 was not related to the sex, age, smoking status and histology of lung cancer ( $p>0.05$ ) (Figure 2B). However, poorly differentiated lung cancer showed a highly expressed MMP2 $(10 / 19,52.6 \%)$ compared with well differentiated lung cancer $(2 / 14,14.3 \%) \quad(p=0.022)$

(Figure 2C). In addition, the expression of MMP2 in lung cancer at T3-4 stage (12/19, 63.2\%) was significantly higher than that in lung cancer at T1-2 stage $(8 / 37,21.6 \%)(p=0.032)$ (Figure 2D) and the expression of MMP2 in lung cancer with N2-N3 (18/33, 54.5\%) of lymph node metastasis was upregulated compared with that in lung cancer with N0-N1 $(2 / 23,8.7 \%)(p<0.001)$ (Figure 2E). Moreover, increased MMP2 was displayed in lung cancer tissues at stages IIIA-IV (13/20,65\%), compared with those of stages IA-IIB $(7 / 36,19.4 \%)(p=0.002)$ (Figure 2F). 
The serum level of MMP2 in lung cancer patients was higher than that in benign lung diseases and healthy individuals

In the group of lung cancer patients, the concentration of serum MMP2 was $307.14 \pm 96.44 \mathrm{ng} / \mathrm{mL}$, which was significantly higher than that of the benign lung diseases group $(203.15 \pm 52.64 \mathrm{ng} / \mathrm{mL})$ and the healthy control group $(156.23 \pm 76.97 \mathrm{ng} / \mathrm{mL})$, the differences between three groups were statistically significant $(p<0.05)$ (Table 3, Figure 3A).

Increased serum level of MMP2 was associated with tumor size, lymph node metastasis and clinical stage of lung cancer

As shown in Table 3, the serum level of MMP2 was not related to the sex, age, smoking status, histology and differentiation degree of lung cancer cells $(p>0.05)$. However, the serum level of MMP2 in lung cancer patients at T3-4 stage $(341.91 \pm 100.28 \mathrm{ng} / \mathrm{mL})$ was significantly higher than that in lung cancer patients T1-2 stage $(224.18 \pm 58.21 \mathrm{ng} / \mathrm{mL})(p<0.001)$ (Figure 3B). And in lung cancer patients with N2-N3 (333.87 $\pm 100.65 \mathrm{ng} / \mathrm{mL}$ ) of lymph node metastasis, the serum level of MMP2 was up-regulated compared with that in patients with N0-N1 $(251.99 \pm 90.99 \mathrm{ng} / \mathrm{mL})(p=0.001)$ (Figure 3C). In addition, lung cancer patients at stages III-IV $(339.09 \pm 103.73 \mathrm{ng} / \mathrm{mL})$ also displayed an increased serum level of MMP2, compared with those of stages I-II $(267.53 \pm 93.10 \mathrm{ng} / \mathrm{mL})(p=0.003)$ (Figure 3D).

Increased MMP2 in lung cancer tissues was related to shorter survival of lung cancer patients

Through the Kaplan-Meier curves, we found that patients who exhibited the high expression of MMP2 demonstrated a significantly shorter post-surgical survival time as compared with patients who expressed low MMP2 ( $p=0.001$ ) (Figure 3E and 3F). Through a multiple regression analysis, we noticed that the high expression of MMP2 appeared to be a significant independent prognostic indicator for survival time of patients $(p<0.001)$, whereas advanced clinical stage of lung cancer was also introduced into the regression equation, which indicated that advanced stage was an important risk factor that decreased post-surgical survival time $(p=0.003)$. The final risk function was $H(t)=\left[h_{0}(t)\right] e^{(2.01 \times 8+1.49 \times 9)}$ (Table 4).

Threshold value and diagnostic accuracy of serum MMP2 for discerning lung cancer from benign lung disease and normal individuals

Through the ROC curves analysis [20], we found that the minimum of serum MMP2 located in the healthy group while the maximum serum MMP2 belonged to the lung cancer group (Table 5). When the serum MMP2 value of $182.8 \mathrm{ng} / \mathrm{mL}$ was defined as a threshold for distinguishing lung cancer from benign lung 
diseases, the sensitivity and specificity of MMP2 serum value reached the best compromise, responding a sensitivity of $96.51 \%$ and specificity of $65.85 \%$ (Figure $4 A$ and $4 B$ ). Statistical analysis showed that the area under the ROC curve (AUC) was 0.851, Standard Error a 0.0374, 95\% Confidence Interval b 0.776 to 0.908 , z statistic 9.379, and significance level $p($ Area $=0.5)<0.0001$ (Table 5, Figure 4 C). In addition, the value of $170.9 \mathrm{ng} / \mathrm{mL}$ seemed to be a threshold to discern the lung cancer from healthy individuals, the sensitivity was 97.67 and the specificity was increased to 75\% (Figure 5A and 5B). Statistical analysis showed that the AUC arrived at 0.909 with 0.0287 of standard error $(95 \% \mathrm{Cl}, 0.850$ to 0.950 , and then $\mathrm{Z}$ value was $14.702(p<0.0001)$ (Table 5, Figure 5C).

\section{Discussion}

Lung cancer is the most common cause of cancer death worldwide [21]. Molecular targeted therapy has shown significant effects on the treatment of tumor cells with somatic-driven oncogene, such as EGFR gene mutations, receptor tyrosine kinase gene (RET) and c-ros proto-oncogene (ROS) rearrangements [22]. So, identification of the abnormal proteins in lung cancer may be of great value in the developing of lung cancer novel diagnostic and therapeutic methods [6]. There is substantial evidence that MMP2 plays a major role in tumor cell-mediated degradation of extracellular matrix and its expression is closely related to the invasion, metastasis and prognosis of human malignant tumors [8-10, 14]. In this study, by measuring the serum level of MMP2 in patients with lung cancer, we explored the relationship between the MMP2 and the biological behavior of lung cancer invasion and metastasis.

In tissues level, we found that the MMP2 was highly expressed in lung cancer tissues but not in adjacent normal tissues, which suggested that high expression of MMP2 might potentially promote lung cancer occurrence and development. Previous studies have demonstrated that MMP2 is highly expressed in lung cancer tissues and lowly expressed in normal tissues [23, 24]. It is well known that the degree of differentiation of lung cancer cells is an independent factor affecting the prognosis of lung cancer patients, which is mainly based on that poorly differentiated lung cancer cells have a high degree of malignancy, and will soon be transferred and relapsed. In our study, we found that MMP2 was highly expressed in poorly differentiated lung cancer tissues, indicating that the high expression of MMP2 is associated with the malignant degree of lung cancer. Moreover, we found that the increased MMP2 in lung cancer tissues correlated significantly with lymph node metastasis and advanced TNM stage. In the analysis of the correlation between tumor size and MMP2 expression, we also noticed that with the increase of tumor volume, the expression of MMP2 showed an increasing trend. These results will show a clear suggestion that determining the expression of MMP2 is a valuable strategy for predicting the metastatic potential and prognosis of lung cancer. Previous studies have suggested that the MMP2 is associated with the molecular classification of some malignant tumors and has a close relationship with invasiveness, proliferation, lymphatic metastasis, and poor prognosis [9-11, 14], and our findings are similar to this.

Importantly, our study also showed that serum level of MMP2 in lung cancer patients significantly higher than that in benign lung disease group and healthy control group, thus suggesting a possible mechanism 
that MMP2 may be released from lung cancer cells to help the progress and spread of cancer cells. Some researches have showed that MMP2 secretion is increased during tumor formation and progression, so the amount of MMP2 in the blood circulation is detected by peripheral blood has been reported $[25,26]$. TNM stage correlates with the prognosis of cancer patients, which is mainly based on lymph node metastasis, tumor size, and distant metastasis. Our study showed that increased serum MMP2 significantly correlated with the malignant features of lung cancer such as tumor size, invasion and metastasis of lymph nodes, low differentiation and advanced stage. The possible mechanisms for MMP2 to promote tumor progression is that MMP2 not only degrades the basement membrane and matrix to break through the matrix barrier, which promotes tumor invasion and metastasis, but also accelerate tumor growth and proliferation through neovascularization [27]. Our findings suggested that the release of MMP2 was significantly increased in the tumorigenesis of lung cancer, suggesting that serum MMP2 could be used as a diagnostic and prognostic indicator of lung cancer.

Through the COX regression analysis, we found that lung cancer patients with over-expression of MMP2 had a shorter survival time compared with those without MMP2 over-expression. In addition, we also found that advanced TNM stage certainly was to be a strong risk factor for shorter survival time of lung cancer patients, with a hazard ratio value of 2.01. In our study, these two factors were implicated into the regression equation and the regression equation was as $\mathrm{H}(\mathrm{t})=\left[\mathrm{h}_{0}(\mathrm{t})\right] \mathrm{e}^{(2.01 \mathrm{X} 8+1.49 \mathrm{X} 9)}$, which suggested that determining the expression of MMP2 in lung cancer tissues is helpful for predicting the prognosis of lung cancer patients. Previous study shows that the high expression of MMP2 in NSCLC was associated with tumor type and clinical stage and has a predictive value for low survival rates, short overall survival (OS) and disease free survival (DFS), suggesting that the use of MMP2 is valuable in determining the patients with more aggressive disease [28]. We also analyzed the diagnostic value of serum MMP2 in patients with lung cancer. When we used serum MMP2 as an indicator to distinguish lung cancer from benign lung disease, it showed a better sensitivity of $96.51 \%$ and a considerable specificity of $65.85 \%$. Previous studies show that tumor cells can secrete a variety of tumor-related proteins that help them proliferate and migrate [2-4, 22]. Increased MMP2 immunostaining and MMP2 serum level correlate with advanced tumor stage and the presence of distant metastasis, and serum MMP2 level may be a valuable prognosis variable and could help to stratify lung cancer patients into low- and high-risk groups [29]. Our findings implied that serum MMP2 level could reflect the situation of progression and migration of lung cancer to a certain extent, which indicated that MMP2 could be a useful diagnostic, prognostic, and predictive biomarker of lung cancer.

A previous study suggests that the expression of MMP2 in tissues is closely related to lung adenocarcinoma, tumor recurrence, OS and DFS [28], however, another study suggests that MMP2 protein has nothing to do with the histology of NSCLC, but its mRNA level correlates with poorly differentiated tissue, distant metastasis and small cell lung cancer [29]. These results indicate that the expression of MMP2 in NSCLC remains controversial yet. In addition to the findings of the above studies, we found that whether in tissues or in serum, MMP2 expression was associated with lymph node metastasis and tumor size and TNM stage. Based on the above results, we can think that MMP2 is associated with the 
occurrence and development of NSCLC, but the relationship between the two is still unclear. In the future, more multi-center, large-scale studies are still needed to solve this problem. More importantly, the intrinsic mechanism of MMP2 affecting the development of NSCLC remains unclear. However, There are opinions that MMP2 suppression decreases the expression of hypoxia inducible factor-1 alpha (HIF-1alpha) and disrupts phosphoinosmde-3-kinase (PI3K) dependent vascular endothelial growth factor (VEGF) expression, and A549 xenograft tissue sections from mice that treated with MMP-2 small interfering RNA shows reduced expressions of VEGF, providing new insights into the mechanisms underlying MMP2mediated VEGF expression in lung tumor angiogenesis [30]. Another new study suggests that silibinin inhibits the MMP2 signaling pathway, and inhibits the proliferation, migration, and invasion of triplenegative breast cancer cells [31].

There are still some shortcomings in this study. Firstly, most patients of the surgical resection belong to patients with clinical stage IIIB and before, which may leads to a selective bias of the specimen. Secondly, the number of patients included is relatively small. Thirdly, this study did not concern the specific mechanisms by which MMP2 affects the growth, proliferation and metastasis of lung cancer cells. Hence, further experiments involving the mutual regulation-mechanism of MMP2 in lung cancer cells should be done. Fourthly, the study was a retrospective study, so used two independent patient groups to detect the MMP2 expression in lung cancer tissues and serum, which may weaken the strength of the evidence. In the future, further studies need to be performed to prove our conclusion more effectively through the method of detecting both expression levels of the tissue and the serum of MMP2 in the same patient.

\section{Conclusions}

We found that the expression of MMP2 was increased in tissues and serum of lung cancer patients and that increased MMP2 correlated with poorly differentiated cancer, tumor size, lymphatic metastasis and advanced TNM stage. In addition, up-regulation of MMP2 in lung cancer tissues was correlated to a shorter survival of patients. Moreover, increased serum MMP2 contributes to the diagnosis and prognosis of lung cancer patients, which indicated that MMP2 could be a useful diagnostic, prognostic, and predictive biomarker of lung cancer.

\section{Abbreviations}

ABC: avidin-biotin-peroxidasecomplex; AUC: area under the ROC curve; DNA: deoxyribonucleic acid; DFS: disease free survival; ECM: extracellular matrix; EDTA: ethylene diamine tetraacetic acid; EGFR: epidermal growth factor receptor; ELISA: enzyme linked immunosorbent assay; HIF-1 alpha: hypoxia inducible factor-1alph; IHC: immunohistochemistry; MMP2: matrix metalloproteinase 2; MMPs; matrix metalloproteinases; $\mathrm{M} \pm \mathrm{SD}$ : mean \pm standard deviation; NSCLC: non-small cell lung carcinomas; OS: Overall survival; PBS: phosphate buffer saline; PI3K: phosphoinosmde-3-kinase; RET: receptor tyrosine kinase gene; ROC: receiver operating characteristic; ROS: c-ros proto-oncogene; SCLC: small-cell lung carcinomas; SPSS: statistical product and service solutions; TBST: mixture of tris-buffered saline and 
polysorbate 20; TMA: tissue microarray; TMB: tetramethylbenzidine; VEGF: vascular endothelial growth factor.

\section{Declarations Section}

Ethics approval and consent to participate

The study was approved by Research Ethics Committee of Jining NO.1 People's Hospital, Jining, China.

\section{Consent for publication}

Not applicable.

\section{Availability of data and materials}

The datasets supporting the conclusions of this article are included within the article.

\section{Competing interests}

None.

\section{Funding}

None.

\section{Authors' contributions}

LP H, BW S, QD Z, W Y and QF J participated in the design of the study, carried out the study, statistical analysis of studies and wrote the manuscript. All authors have read and approved the manuscript, and ensure that this is the case.

\section{Acknowledgements}

This work was supported by the Science Foundation of Jining NO.1 People's Hospital and Affiliated Jining NO.1 People's Hospital of Jining Medical University, Jining Medical University, China. 


\section{References}

1. Jin S, Deng Y, Hao JW, Li Y, Liu B, Yu Y, Shi FD, Zhou QH: NK cell phenotypic modulation in lung cancer environment. PloS one 2014, 9(10):e109976.

2. Larsen JE, Minna JD: Molecular biology of lung cancer: clinical implications. Clin Chest Med 2011, 32(4):703-740.

3. Lemjabbar-Alaoui H, Hassan OU, Yang YW, Buchanan P: Lung cancer: Biology and treatment options. Biochim Biophys Acta 2015, 1856(2):189-210.

4. Shtivelman E, Hensing T, Simon GR, Dennis PA, Otterson GA, Bueno R, Salgia R: Molecular pathways and therapeutic targets in lung cancer. Oncotarget 2014, 5(6):1392-1433.

5. Mohammed AA, El-Tanni H, Alsakkaf MA, Mirza AA, Atiah TA, Atiah AA: Genomic aberrations in nonsmall cell lung cancer and their impact on treatment outcome. J Cancer Res Ther2017, 13(1):9-15.

6. Rong B, Nan Y, Liu H, Gao W: Increased stathmin correlates with advanced stage and poor survival of non-small cell lung cancer. Cancer biomarkers : section A of Disease markers 2017, 19(1):35-43.

7. Kunz P, Sahr H, Lehner B, Fischer C, Seebach E, Fellenberg J: Elevated ratio of MMP2/MMP9 activity is associated with poor response to chemotherapy in osteosarcoma. BMC Cancer 2016, 16:223.

8. Wang B, Ding YM, Fan P, Xu JH, Wang WX: Expression and significance of MMP2 and HIF-1alpha in hepatocellular carcinoma. Oncol Lett 2014, 8(2):539-546.

9. Liu RR, Li MD, Li T, Tan Y, Zhang M, Chen JC: Matrix metalloproteinase 2 (MMP2) protein expression and laryngeal cancer prognosis: a meta analysis. Int J Clin Exp Med 2015, 8(2):2261-2266.

10. Ren F, Tang R, Zhang X, Madushi WM, Luo D, Dang Y, Li Z, Wei K, Chen G: Overexpression of MMP Family Members Functions as Prognostic Biomarker for Breast Cancer Patients: A Systematic Review and Meta-Analysis. PloS one 2015, 10(8):e0135544.

11. Liu C: Pathological and prognostic significance of matrix metalloproteinase-2 expression in ovarian cancer: a meta-analysis. Clin Exp Med 2016, 16(3):375-382.

12. Chen $Y$, Wang $X$, Chen $G$, Dong $C$, Zhang $D$ : The impact of matrix metalloproteinase 2 on prognosis and clinicopathology of breast cancer patients: a systematic meta-analysis. PloS one 2015, 10(3):e0121404.

13. Wang HL, Zhou PY, Zhang Y, Liu P: Relationships between abnormal MMP2 expression and prognosis in gastric cancer: a meta-analysis of cohort studies. Cancer Biother Radiopharm 2014, 29(4):166-172.

14. Wen X, Liu H, Yu K, Liu Y: Matrix metalloproteinase 2 expression and survival of patients with osteosarcoma: a meta-analysis. Tumour biology : the journal of the International Society for Oncodevelopmental Biology and Medicine 2014, 35(1):845-848.

15. Lou C, Zhu Z, Zhao Y, Zhu R, Zhao H: Arctigenin, a lignan from Arctium lappa L., inhibits metastasis of human breast cancer cells through the downregulation of MMP-2/-9 and heparanase in MDA-MB231 cells. Oncol Rep 2017, 37(1):179-184. 
16. Li C, Deng L, Shen H, Meng Q, Qian A, Sang H, Xia J, Li X: 0-6-methylguanine-DNA Methyltransferase Inhibits Gastric Carcinoma Cell Migration and Invasion by Downregulation of Matrix Metalloproteinase 2. Anticancer Agents Med Chem 2016, 16(9):1125-1132.

17. Poudel B, Ki HH, Luyen BT, Lee YM, Kim YH, Kim DK: Triticumoside induces apoptosis via caspasedependent mitochondrial pathway and inhibits migration through downregulation of MMP2/9 in human lung cancer cells. Acta Biochim Biophys Sin (Shanghai) 2016, 48(2):153-160.

18. Biaoxue R, Xiling J, Shuanying Y, Wei Z, Xiguang C, Jinsui W, Min Z: Upregulation of Hsp90-beta and annexin $\mathrm{A} 1$ correlates with poor survival and lymphatic metastasis in lung cancer patients. $\mathrm{J}$ Exp Clin Cancer Res 2012, 31:70.

19. Biaoxue R, Shuanying Y, Wei L, Zongjuan M, Xiguang C, Qiuhong Z: Co-overexpression of Hsp90-beta and annexin $\mathrm{A} 1$ with a significantly positive correlation contributes to the diagnosis of lung cancer. Expert Rev Mol Diagn 2014, 14(8):1067-1079.

20. Biaoxue R, Hua L, Tian F, Wenlong G: Increased stathmin in serum as a potential tumor marker for lung adenocarcinoma. Jpn J Clin Oncol 2017, 47(4):342-349.

21. Ansari J, Shackelford RE, El-Osta H: Epigenetics in non-small cell lung cancer: from basics to therapeutics. Transl Lung Cancer Res 2016, 5(2):155-171.

22. Park JY, Jang SH: Epidemiology of Lung Cancer in Korea: Recent Trends. Tuberc Respir Dis (Seoul) 2016, 79(2):58-69.

23. Zhang L, Li N, Yan HC, Jiang H, Fang XJ: Expression of Novel CD44st and MMP2 in NSCLC Tissues and Their Clinical Significance. Oncol Res Treat 2017, 40(4):192-196.

24. Jiang LY, Bi R, Ding FB, Wang MS, Mei J, He Y: Prognostic significance of overexpressed matrix metalloproteinase-2, mouse-double minute: 2 homolog and epidermal growth factor receptor in nonsmall cell lung cancer. J BUON 2016, 21(2):341-348.

25. Wu CY, Wu MS, Chiang EP, Chen YJ, Chen CJ, Chi NH, Shih YT, Chen GH, Lin JT: Plasma matrix metalloproteinase-9 level is better than serum matrix metalloproteinase-9 level to predict gastric cancer evolution. Clin Cancer Res 2007, 13(7):2054-2060.

26. Yeh YC, Sheu BS, Cheng HC, Wang YL, Yang HB, Wu JJ: Elevated serum matrix metalloproteinase-3 and -7 in $\mathrm{H}$. pylori-related gastric cancer can be biomarkers correlating with a poor survival. Dig Dis Sci 2010, 55(6):1649-1657.

27. Mitsiades N, Poulaki V, Kotoula V, Leone A, Tsokos M: Fas ligand is present in tumors of the Ewing's sarcoma family and is cleaved into a soluble form by a metalloproteinase. Am J Pathol 1998, 153(6):1947-1956.

28. Leinonen T, Pirinen R, Bohm J, Johansson R, Kosma VM: Increased expression of matrix metalloproteinase-2 (MMP-2) predicts tumour recurrence and unfavourable outcome in non-small cell lung cancer. Histol Histopathol 2008, 23(6):693-700.

29. Guo CB, Wang S, Deng C, Zhang DL, Wang FL, Jin XQ: Relationship between matrix metalloproteinase 2 and lung cancer progression. Mol Diagn Ther 2007, 11(3):183-192. 
30. Chetty C, Lakka SS, Bhoopathi P, Rao JS: MMP-2 alters VEGF expression via alphaVbeta3 integrinmediated PI3K/AKT signaling in A549 lung cancer cells. Int J Cancer 2010, 127(5):1081-1095.

31. Byun HJ, Darvin P, Kang DY, Sp N, Joung YH, Park JH, Kim SJ, Yang YM: Silibinin downregulates MMP2 expression via Jak2/STAT3 pathway and inhibits the migration and invasive potential in MDA-MB-231 cells. Oncol Rep 2017, 37(6):3270-3278.

\section{Tables}


Table 1 Clinico-pathological features of patients involve in the study

\begin{tabular}{|c|c|c|c|c|c|}
\hline \multirow[b]{2}{*}{ Items } & \multicolumn{2}{|c|}{$\begin{array}{l}\text { Lung cancer patients for } \\
\text { tissues test }\end{array}$} & \multicolumn{3}{|c|}{ Lung cancer patients for serum test } \\
\hline & Characteristics & $\begin{array}{c}\text { Lung cancer } \\
\text { patients } \\
(\mathrm{N}=65)\end{array}$ & $\begin{array}{c}\text { Lung } \\
\text { cancer } \\
\text { patients } \\
(\mathrm{N}=86)\end{array}$ & $\begin{array}{c}\text { Benign lung } \\
\text { disease } \\
(\mathrm{N}=41)\end{array}$ & $\begin{array}{c}\text { Healthy } \\
\text { individuals } \\
(\mathrm{N}=66)\end{array}$ \\
\hline Gender & Male & $51(78.5 \%)$ & $54(62.8 \%)$ & $26(63.4 \%)$ & $40(60.6 \%)$ \\
\hline & Female & $14(21.5 \%)$ & $32(37.2 \%)$ & $15(36.6 \%)$ & $26(39.4 \%)$ \\
\hline \multicolumn{6}{|l|}{ Ages } \\
\hline & $<60$ & $33(50.8 \%)$ & $40(46.5 \%)$ & $19(46.3 \%)$ & $25(37.9 \%)$ \\
\hline & $\geq 60$ & $32(49.2 \%)$ & $46(53.5 \%)$ & $22(53.7 \%)$ & $41(62.1 \%)$ \\
\hline \multicolumn{6}{|l|}{ Smoking } \\
\hline & Yes & $34(52.3 \%)$ & $53(61.6 \%)$ & 13(31.7\%) & $24(36.4 \%)$ \\
\hline & No & $31(47.7 \%)$ & $33(38.4 \%)$ & $28(68.3 \%)$ & $42(63.6 \%)$ \\
\hline \multicolumn{6}{|l|}{ Histology } \\
\hline & LAC & $25(38.5 \%)$ & $33(38.4 \%)$ & & \\
\hline & LSCC & $31(47.7 \%)$ & $39(45.3 \%)$ & & \\
\hline & SCLC & $9(13.8 \%)$ & $14(16.3 \%)$ & & \\
\hline \multicolumn{6}{|l|}{$\begin{array}{l}\text { Differentiation } \\
\text { degree }\end{array}$} \\
\hline & Poorly & $19(29.2 \%)$ & $23(26.7 \%)$ & & \\
\hline & Moderately & $23(35.5 \%)$ & $25(29.1 \%)$ & & \\
\hline & Well & $14(21.5 \%)$ & $24(27.9 \%)$ & & \\
\hline & Unavailable & $9(13.8 \%)$ & $14(16.3 \%)$ & & \\
\hline \multicolumn{6}{|l|}{ T staging } \\
\hline & T1-T2 & $37(56.9 \%)$ & $23(26.7 \%)$ & & \\
\hline & T3-T4 & $19(29.2 \%)$ & $49(57 \%)$ & & \\
\hline & Unavailable & $9(13.9 \%)$ & $14(16.3 \%)$ & & \\
\hline \multicolumn{6}{|l|}{$\begin{array}{l}\text { Lymphatic } \\
\text { metastasis }\end{array}$} \\
\hline & N0 - N1 & $23(35.4 \%)$ & $26(30.2 \%)$ & & \\
\hline & N2 - N3 & $33(50.8 \%)$ & $46(53.5 \%)$ & & \\
\hline & Unavailable & $9(13.8 \%)$ & $14(16.3 \%)$ & & \\
\hline \multicolumn{6}{|l|}{$\begin{array}{l}\text { Clinical } \\
\text { staging }\end{array}$} \\
\hline & I-II & $36(55.4 \%)$ & $35(40.7 \%)$ & & \\
\hline & III-IV & $20(30.8 \%)$ & $37(43.2 \%)$ & & \\
\hline & Unavailable & $9(13.8 \%)$ & $14(16.3 \%)$ & & \\
\hline
\end{tabular}

LAC, lung adenocarcinoma; LSCC, lung squamous cell carcinoma; SCLC, small cell lung cancer; $\mathrm{N}$, the grade of lymphatic invasion.

Table 2 The expression of MMP2 in lung cancer tissues $(\mathrm{N}=65)$ 


\begin{tabular}{|c|c|c|c|c|c|c|c|}
\hline \multirow[t]{2}{*}{ Parameter } & \multirow[t]{2}{*}{ Group } & \multirow[t]{2}{*}{$\mathrm{N}$} & \multicolumn{5}{|c|}{ Expression of MMP2 } \\
\hline & & & Low (\%) & $\begin{array}{c}\text { Moderate } \\
(\%)\end{array}$ & High (\%) & $\begin{array}{c}\chi^{2} \\
\text { value }\end{array}$ & $\begin{array}{c}P \\
\text { value }\end{array}$ \\
\hline \multirow[t]{2}{*}{ Category } & Normal & 65 & $33(50.8)$ & $19(29.2)$ & 13(20) & \multirow[t]{2}{*}{12.342} & \multirow[t]{2}{*}{0.002} \\
\hline & Cancerous & 65 & $14(21.5)$ & $27(41.5)$ & $24(37)^{\bullet}$ & & \\
\hline \multirow{2}{*}{ Gender } & & & & & & \multirow[b]{2}{*}{2.195} & \multirow[b]{2}{*}{0.334} \\
\hline & Male & 51 & 13(25.5) & $20(39.2)$ & 18(35.3) & & \\
\hline \multirow{2}{*}{ Ages } & remare & 14 & & & & & \\
\hline & $<60$ & 33 & $7(21.2)$ & $15(45.5)$ & $11(33.3)$ & \multirow{2}{*}{0.482} & \multirow{2}{*}{0.785} \\
\hline & $\geq 60$ & 32 & $7(21.9)$ & $12(37.5)$ & $13(40.6)$ & & \\
\hline \multirow[t]{3}{*}{ Smoking } & & & & & & \multirow{3}{*}{1.044} & \multirow{3}{*}{0.593} \\
\hline & Yes & 34 & $9(26.5)$ & $13(38.2)$ & $12(35.3)$ & & \\
\hline & No & 31 & $5(16.1)$ & $14(45.2)$ & $12(38.7)$ & & \\
\hline \multirow{3}{*}{ Histology } & I $A C$ & 25 & $5(20)$ & $13(52)$ & $7(28)$ & \multirow{3}{*}{2.011} & \multirow{3}{*}{0.734} \\
\hline & LSCC & 31 & $7(22.6)$ & $11(35.5)$ & $13(41.9)$ & & \\
\hline & SCLC & 9 & $2(22.2)$ & $3(33.3)$ & $4(44.4)$ & & \\
\hline \multirow{5}{*}{$\begin{array}{l}\text { Pathological } \\
\text { grade }\end{array}$} & & & & & & \multirow{5}{*}{11.46} & \multirow{5}{*}{0.022} \\
\hline & Poorly & 19 & $1(5.3)$ & $8(42.1)$ & $10(52.6)^{\square}$ & & \\
\hline & Moderately & 23 & $4(17.4)$ & $11(47.8)$ & $8(34.8)$ & & \\
\hline & Well & 14 & $7(50)$ & $5(35.7)$ & $2(14.3)$ & & \\
\hline & Unavailable & 9 & $2(22.2)$ & $3(33.3)$ & $4(44.4)$ & & \\
\hline \multirow[t]{2}{*}{ T staging } & & & & & & \multirow{3}{*}{10.567} & \multirow{3}{*}{0.032} \\
\hline & $\begin{array}{l}\mathrm{T} 1-\mathrm{T} 2 \\
\mathrm{~T} 3-\mathrm{T} 4\end{array}$ & $\begin{array}{l}3 \% \\
19\end{array}$ & $\begin{array}{c}11(29.7) \\
1(5.3)\end{array}$ & $\begin{array}{c}18(48.6) \\
6(316)\end{array}$ & $8(21.6)$ & & \\
\hline & Unavailable & 9 & $2(22.2)$ & $3(33.3)$ & $4(44.4)$ & & \\
\hline \multirow[t]{4}{*}{$\begin{array}{l}\text { Lymph node } \\
\text { metastasis }\end{array}$} & & & & & & \multirow{4}{*}{17.06} & \multirow{4}{*}{$<0.001$} \\
\hline & N0 - N1 & 23 & $10(43.5)$ & $11(47.8)$ & $2(8.7)$ & & \\
\hline & N2 - N3 & 33 & $2(6.1)$ & $13(39.4)$ & $18(54.5) \square$ & & \\
\hline & Unavailable & 9 & $2(22.2)$ & $3(33.3)$ & $4(44.4)$ & & \\
\hline \multirow{3}{*}{ pTNM } & IA-IIB & 36 & $11(30.6)$ & $18(50)$ & $7(19.4)$ & \multirow{3}{*}{12.59} & 0.002 \\
\hline & IIIA-IV & 20 & $1(5)$ & $6(30)$ & $13(65)^{\square}$ & & \\
\hline & Unavailable & 9 & $2(22.2)$ & $3(33.3)$ & $4(44.4)$ & & \\
\hline
\end{tabular}

$\mathrm{N}$, numbers of patients; ${ }^{\bullet} p<0.05$, cancerous tissues compared with normal tissues; ${ }^{\square} p<0.05$, Poorly differentiated tissues compared with well differentiated tissues; $\mathbf{\Lambda}_{p<0.05}$, T3-4 compared with T1-2; $\boldsymbol{m}_{p}<0.05$, N2-N3 of lymph node metastasis compared with N0-N1; ${ }^{\square} p<0.05$, IIIA-IV compared with IA-IIB; LAC, lung adenocarcinoma; LSCC, lung squamous cell carcinoma; SCLC, small cell lung cancer. 
Table 3 Correlation between clinico-pathological parameters and the expressions of MMP2 in serum of NSCLC $(n=86)$

\begin{tabular}{|c|c|c|c|c|c|c|}
\hline \multirow[t]{2}{*}{ Parameter } & \multirow[t]{2}{*}{ Group } & \multirow[t]{2}{*}{$\mathrm{N}$} & \multicolumn{4}{|c|}{ Expressions of MMP2 in serum of NSCLC } \\
\hline & & & Value (ng/ml) & $\begin{array}{l}\text { Degree of } \\
\text { freedom }\end{array}$ & $\begin{array}{l}\text { Statistical } \\
\text { value }\end{array}$ & $\begin{array}{c}P \\
\text { value }\end{array}$ \\
\hline \multirow[t]{3}{*}{ Category } & Normal & 60 & $156.23 \pm 76.97$ & \multirow{3}{*}{2} & \multirow{3}{*}{64.22} & \multirow{3}{*}{$<0.001$} \\
\hline & Benign & 41 & $203.15 \pm 52.64$ & & & \\
\hline & Cancerous & 86 & $307.14 \pm 96.44$ & & & \\
\hline \multirow[t]{3}{*}{ Gender } & & & & \multirow{3}{*}{1} & \multirow{3}{*}{0.038} & \multirow{3}{*}{0.846} \\
\hline & Male & 54 & $308.70 \pm 97.60$ & & & \\
\hline & Female & 32 & $304.50 \pm 97.03$ & & & \\
\hline \multirow[t]{2}{*}{ Ages } & & & & \multirow{3}{*}{1} & & \multirow{3}{*}{0.272} \\
\hline & $<60$ & 40 & $294.82 \pm 73.63$ & & \multirow[t]{2}{*}{1.221} & \\
\hline \multirow{3}{*}{ Smoking } & $\geq 00$ & 40 & $31 / .85 \pm 112.39$ & & & \\
\hline & Yes & 53 & $300.17 \pm 96.47$ & \multirow{2}{*}{1} & \multirow{2}{*}{0.717} & \multirow{2}{*}{0.400} \\
\hline & No & 33 & $318.32 \pm \underline{ \pm 96.91}$ & & & \\
\hline \multirow{3}{*}{ Histology } & LAC. & & $29359+9581$ & \multirow{3}{*}{2} & \multirow{3}{*}{0.560} & \multirow{3}{*}{0.573} \\
\hline & LSCC & 39 & $313.37 \pm 111.62$ & & & \\
\hline & SCLC & 14 & $321.69 \pm 32.20$ & & & \\
\hline \multirow{5}{*}{$\begin{array}{l}\text { Pathological } \\
\text { grade }\end{array}$} & & & & & & \\
\hline & Poorly & 23 & $305.95 \pm 105.18$ & \multirow[t]{4}{*}{3} & \multirow[t]{4}{*}{0.982} & \multirow[t]{4}{*}{0.405} \\
\hline & Moderately & 25 & $325.13 \pm 109.48$ & & & \\
\hline & Well & 24 & $281.03 \pm 97.63$ & & & \\
\hline & Unavailable & 14 & $321.69 \pm 32.20$ & & & \\
\hline \multirow{4}{*}{ T staging } & & & & \multirow{4}{*}{2} & & \\
\hline & T1-T2 & 23 & $224.18 \pm 58.21$ & & 27.256 & $<0.001$ \\
\hline & T3-T4 & 49 & $341.91 \pm 100.28^{\square}$ & & & \\
\hline & Unavailable & 14 & $321.69 \pm 32.20$ & & & \\
\hline Lymphatic & & & & & & \\
\hline & N0 - N1 & 26 & $251.99 \pm 90.99$ & 2 & 11.759 & 0.001 \\
\hline & N2 - N3 & 46 & $333.87 \pm 100.65^{\boldsymbol{\Lambda}}$ & & & \\
\hline & Unavailable & 14 & $321.69 \pm 32.20$ & & & \\
\hline$\theta+1 \sqrt{101}$ & I-II & 35 & $267.53 \pm 93.10$ & 2 & 9.46 & 0.003 \\
\hline & III-IV & 37 & $339.09 \pm 103.73^{\square}$ & & & \\
\hline & Unavailable & 14 & $321.69 \pm 32.20$ & & & \\
\hline
\end{tabular}

$\underline{\mathrm{M} \pm \mathrm{SD}}$, mean$\underline{\underline{ \pm}}$ standard deviation; LAC, lung adenocarcinoma; LSCC, lung squamous cell carcinoma; SCLC, small cell lung cancer; $\bullet^{\bullet} p<0.05$, cancerous compared with benign and normal; ${ }^{\square} p<0.05$, T3-4 compared with T1-2; ${ }^{\wedge} p<0.05$, N2-N3 of lymph node metastasis compared with N0-N1; ${ }^{\natural}<0.05$, III-IV compared with I-II. TNM, the TNM Classification of Malignant Tumours. 
Table 4 Multiple regression analysis of the relationship between MMP2 and lung cancer

\begin{tabular}{|c|c|c|c|c|c|}
\hline \multirow[t]{2}{*}{ Variables $(\mathrm{X})$} & \multirow[t]{2}{*}{ Categories (different groups) } & \multirow{2}{*}{$\begin{array}{r}\mathrm{P} \\
\text { value }\end{array}$} & \multirow{2}{*}{$\begin{array}{r}\mathrm{OR} \\
\text { value }\end{array}$} & \multicolumn{2}{|c|}{$95 \%$ CI for OR } \\
\hline & & & & lower & upper \\
\hline Gender (X1) & Male $\left(\mathrm{X}_{1-0}\right)$ vs. female $\left(\mathrm{X}_{1-1}\right)$ & 0.154 & 0.532 & 0.223 & 1.267 \\
\hline Age (X2) & $<60\left(\mathrm{X}_{2-0}\right)$ vs. $\geq 60\left(\mathrm{X}_{2-1}\right)$ & 0.618 & 0.808 & 0.422 & 1.671 \\
\hline Smoking (X3) & No $\left(X_{3-0}\right)$ vs. Yes $\left(X_{3-2}\right)$ & 0.558 & 0.810 & 1.401 & 1.637 \\
\hline Histology (X4) & $\begin{array}{r}\text { LAC }\left(\mathrm{X}_{4-0}\right) \text { vs. LSCC }\left(\mathrm{X}_{4^{-} 1}\right) \text { vs. SC } \\
\text { LC }\left(\mathrm{X}_{4^{-} 2}\right)\end{array}$ & 0.300 & 0.702 & 0.360 & 1.370 \\
\hline $\begin{array}{r}\text { Differentiation } \\
\text { (X5) }\end{array}$ & $\begin{array}{r}\text { Poor }\left(\mathrm{X}_{5-0}\right) \text { vs. moderate }\left(\mathrm{X}_{5-1}\right) \\
\text { vs. well }\left(\mathrm{X}_{5-2}\right)\end{array}$ & 0.633 & 0.620 & 0.704 & 1.781 \\
\hline $\begin{array}{r}\text { Lymphatic } \\
\text { invasion (X6) }\end{array}$ & N0-N1 $\left(\mathrm{X}_{6-0}\right)$ vs. N2-N3 $\left(\mathrm{X}_{6-1}\right)$ & 0.540 & 0.485 & 0.048 & 4.919 \\
\hline T stage (X7) & T1-T2 $\left(\mathrm{X}_{7-0}\right)$ vs. T3-T4 $\left(\mathrm{X}_{7-1}\right)$ & 0.307 & 0.648 & 0.139 & 12.32 \\
\hline TNM (X8) & IIA - IIIA $\left(\mathrm{X}_{8-0}\right)$ vs. IIIB - IV $\left(\mathrm{X}_{8-1}\right)$ & 0.003 & 2.01 & 2.013 & 3.078 \\
\hline HSP27 (X9) & $\begin{array}{r}\text { Low }\left(\mathrm{X}_{9-0}\right) \text { vs. moderate }\left(\mathrm{X}_{9-1}\right) \text { vs. } \\
\text { high }\left(\mathrm{X}_{9-2}\right)\end{array}$ & 0.006 & 1.49 & 1.012 & 2.876 \\
\hline & Risk function: & $\mathrm{H}($ & & & \\
\hline
\end{tabular}

LAC, lung adenocarcinoma; LSCC, lung squamous cell carcinoma; SCLC, small cell lung cancer; TNM, clinical stage of lung cancer; OR, odds ratio; CI, confidence interval.

Table 5 Threshold value of serum MMP2 for discerning lung cancer from benign lung disease and normal individuals 


\begin{tabular}{lrrrrrr}
\hline \multicolumn{7}{l}{ Discerning lung cancer from benign lung disease } \\
\hline Criterion & Sensitivity & $95 \%$ CI & Specificity & $95 \%$ CI & + LR & -LR \\
$>=143$ & 100.00 & $95.8-100.0$ & 0.00 & $0.0-8.6$ & 1.00 & \\
\hline$>169$ & 97.67 & $91.9-99.7$ & 24.39 & $12.4-40.3$ & 1.29 & 0.095 \\
\hline 178.4 & 96.51 & $90.1-99.3$ & 58.54 & $42.1-73.7$ & 2.33 & 0.060 \\
\hline$>182.8 *$ & 96.51 & $90.1-99.3$ & 65.85 & $49.4-79.9$ & 2.83 & 0.053 \\
\hline$>238.64$ & 68.60 & $57.7-78.2$ & 75.61 & $59.7-87.6$ & 2.81 & 0.42 \\
\hline$>296.34$ & 46.51 & $35.7-57.6$ & 90.24 & $76.9-97.3$ & 4.77 & 0.59 \\
\hline$>338.8$ & 36.05 & $26.0-47.1$ & 100.00 & $91.4-100.0$ & & 0.64 \\
\hline Discerning lung cancer from normal individuals & & & \\
\hline Criterion & Sensitivity & $95 \%$ CI & Specificity & $95 \%$ CI & + LR & -LR \\
\hline$>134.9$ & 100.00 & $95.8-100.0$ & 65.00 & $51.6-76.9$ & 2.86 & 0.00 \\
$>152.45$ & 97.67 & $91.9-99.7$ & 68.33 & $55.0-79.7$ & 3.08 & 0.034 \\
\hline$>158.6$ & 97.67 & $91.9-99.7$ & 73.33 & $60.3-83.9$ & 3.66 & 0.032 \\
\hline$>170.9 *$ & 97.67 & $91.9-99.7$ & 75.00 & $62.1-85.3$ & 3.91 & 0.031 \\
\hline$>238.64$ & 68.60 & $57.7-78.2$ & 86.67 & $75.4-94.1$ & 5.15 & 0.36 \\
\hline$>325$ & 37.21 & $27.0-48.3$ & 95.00 & $86.1-99.0$ & 7.44 & 0.66 \\
\hline$>467$ & 5.81 & $1.9-13.0$ & 100.00 & $94.0-100.0$ & & 0.94 \\
\hline
\end{tabular}

95\% CI, 95\% confidence; +LR, positive likelihood ratio; -LR, negative likelihood ratio.

Figures 
A

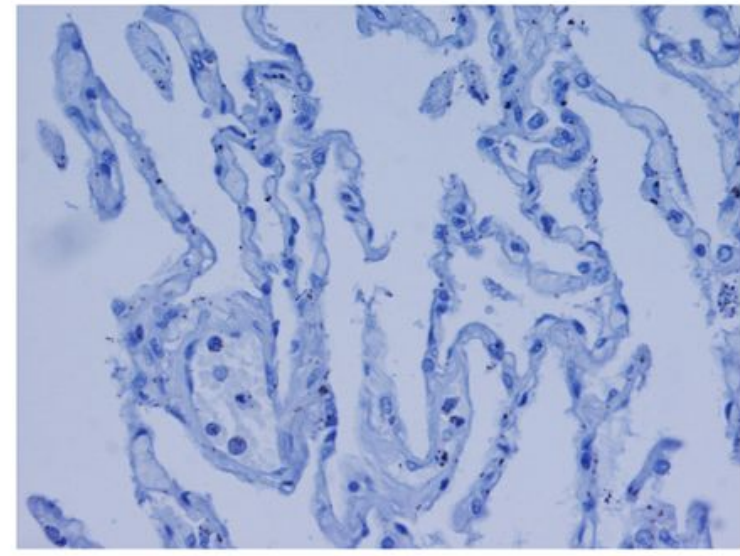

Adjacent normal tissue

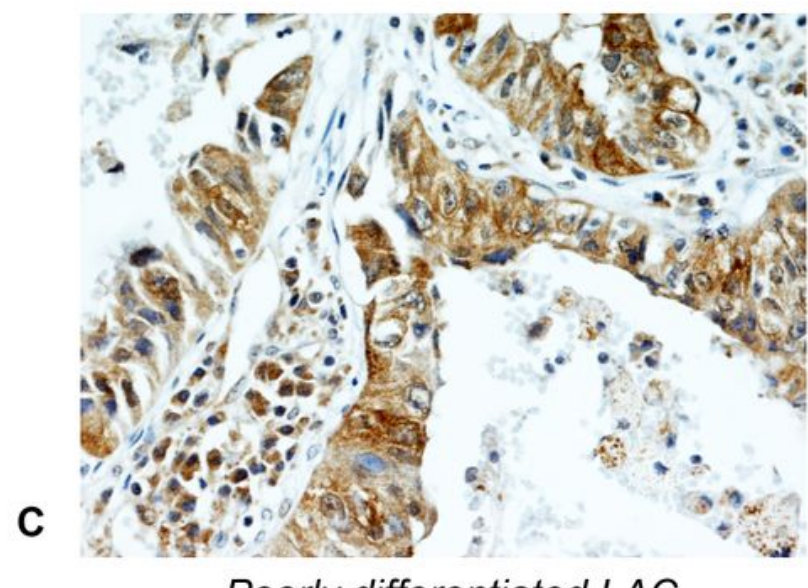

Poorly differentiated LAC

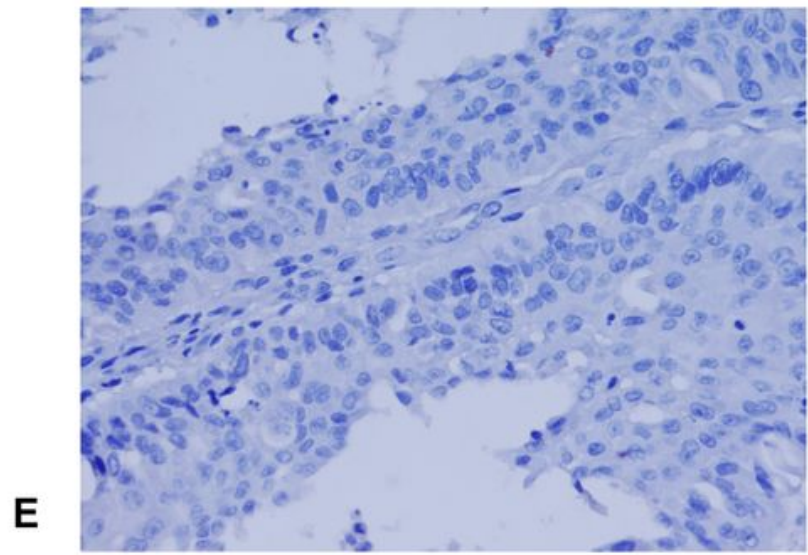

Well differentiated LSCC

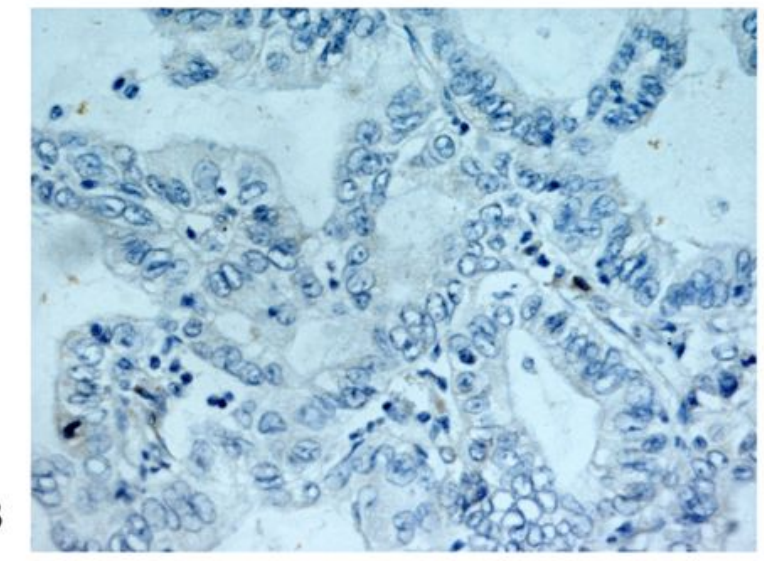

Well differentiated LAC

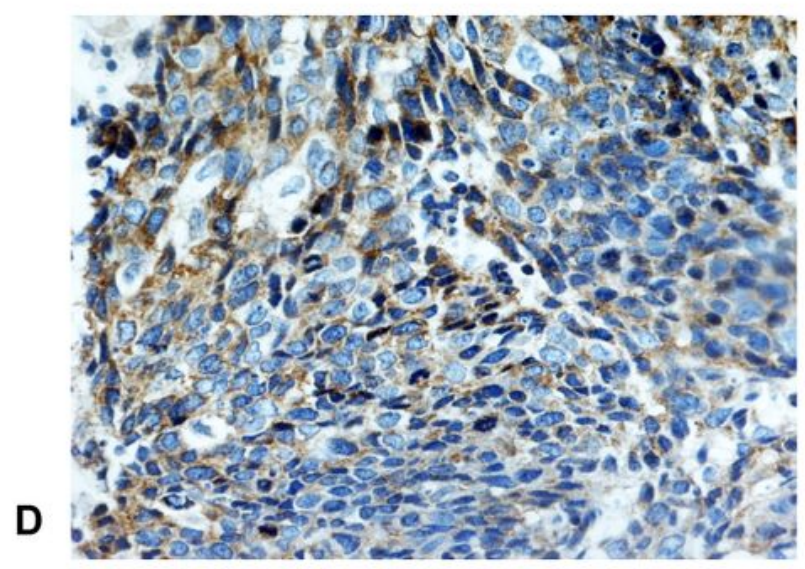

SCLC

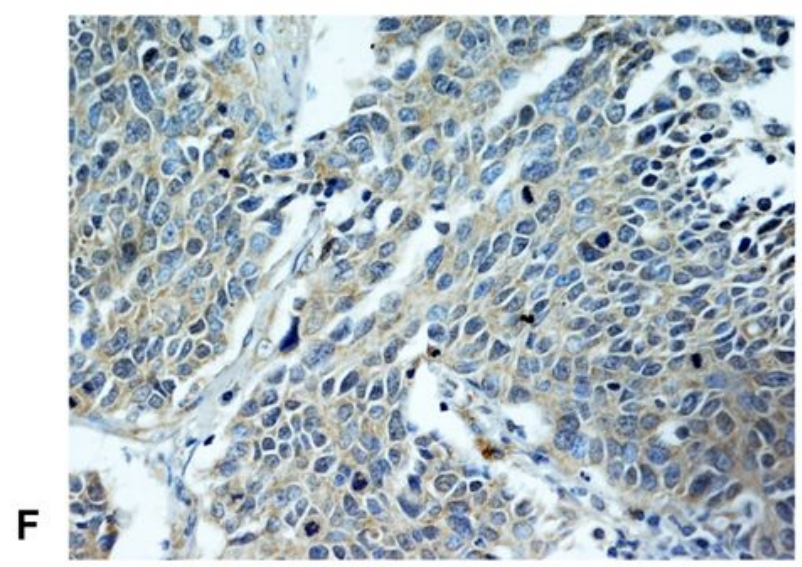

Poorly differentiated LSCC

\section{Figure 1}

IHC analysis of MMP2 in lung cancer and normal tissues (IHC×400). (A) Low expression of MMP2 in normal tissues. (B) Low expression of MMP2 in well differentiated LAC. (C) High expression of MMP2 in poorly differentiated LAC. (D) High expression of MMP2 in SCLC. (E) Low expression of MMP2 in well differentiated LSCC. (F) High expression of MMP2 in poorly differentiated LSCC. SCLC, small cell lung cancer. LAC, lung adenocarcinoma. LSCC, lung squamous cell carcinoma. 
Resourse

A

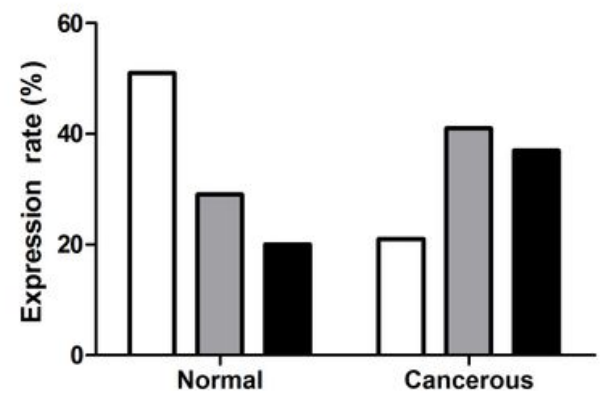

Pathological grade

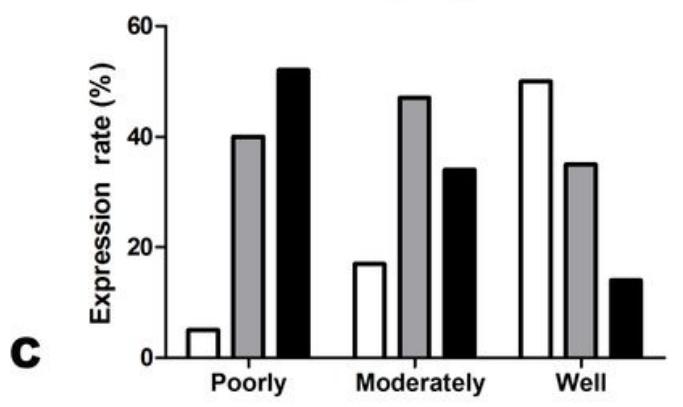

Lymphatic invasion

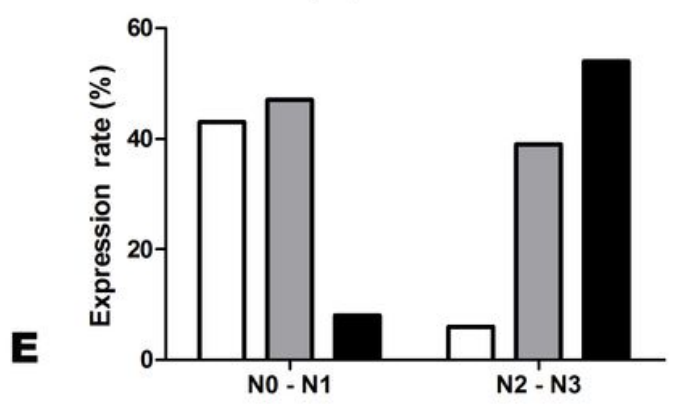

Histology

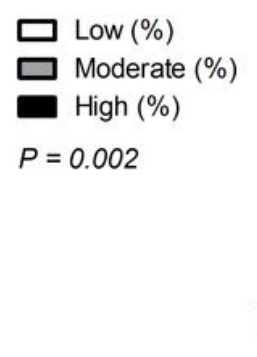

B

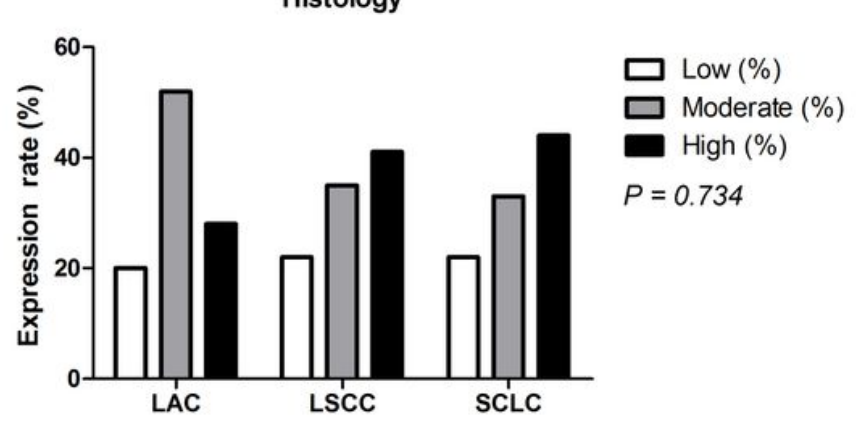

T stage

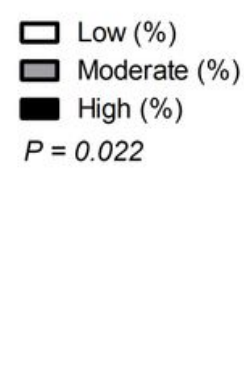

D

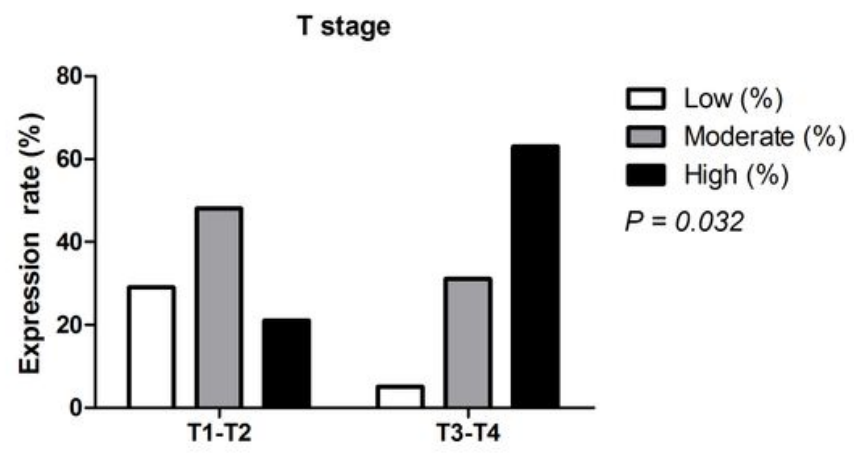

cTNM

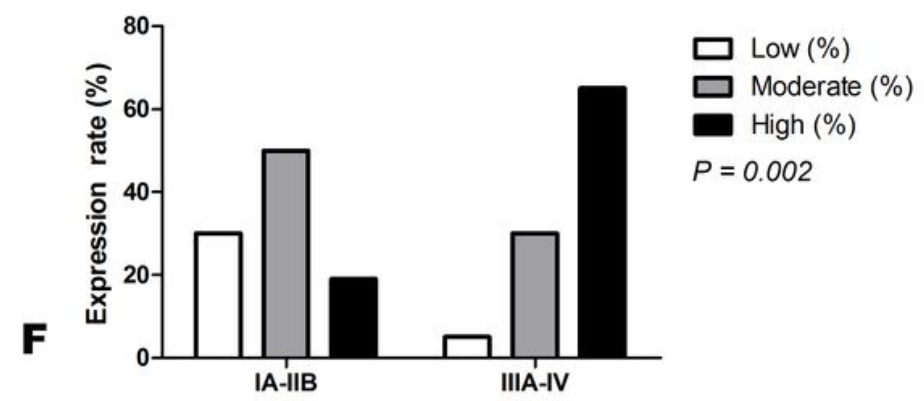

Figure 2

Correlation between clinico-pathological features and the expression of MMP2 in lung cancer tissues. (A) MMP2 was highly expressed in lung cancer tissues, whereas it was lowly expressed in matched adjacent non-malignant tissues $(p<0.05)$. (B) the expression of MMP2 did not relate to the histological type of lung cancer patients ( $p>0.05)$. (C) Upregulation of MMP2 was observed in poorly differentiated lung cancer tissues compared with well-differentiated tissues $(p<0.05)$. (D) The expression of MMP2 in lung cancer tissues at T3-4 stage was significantly higher than that in T1-2 stage $(p<0.05)$. (E) MMP2 expression in lung cancer tissues with N0-N1 of lymphnode metastasis was lower than that in those with N2-N3 of lymph node metastasis $(\mathrm{p}<0.05)$. ( $F)$ Increase of MMP2 was displayed in tissues with lung cancer at stages III-IV compared with those of stages I-II $(p<0.05)$. SCLC, small cell lung cancer. LAC, lung adenocarcinoma. LSCC, lung squamous cell carcinoma. N, node stage (TNM classification). 

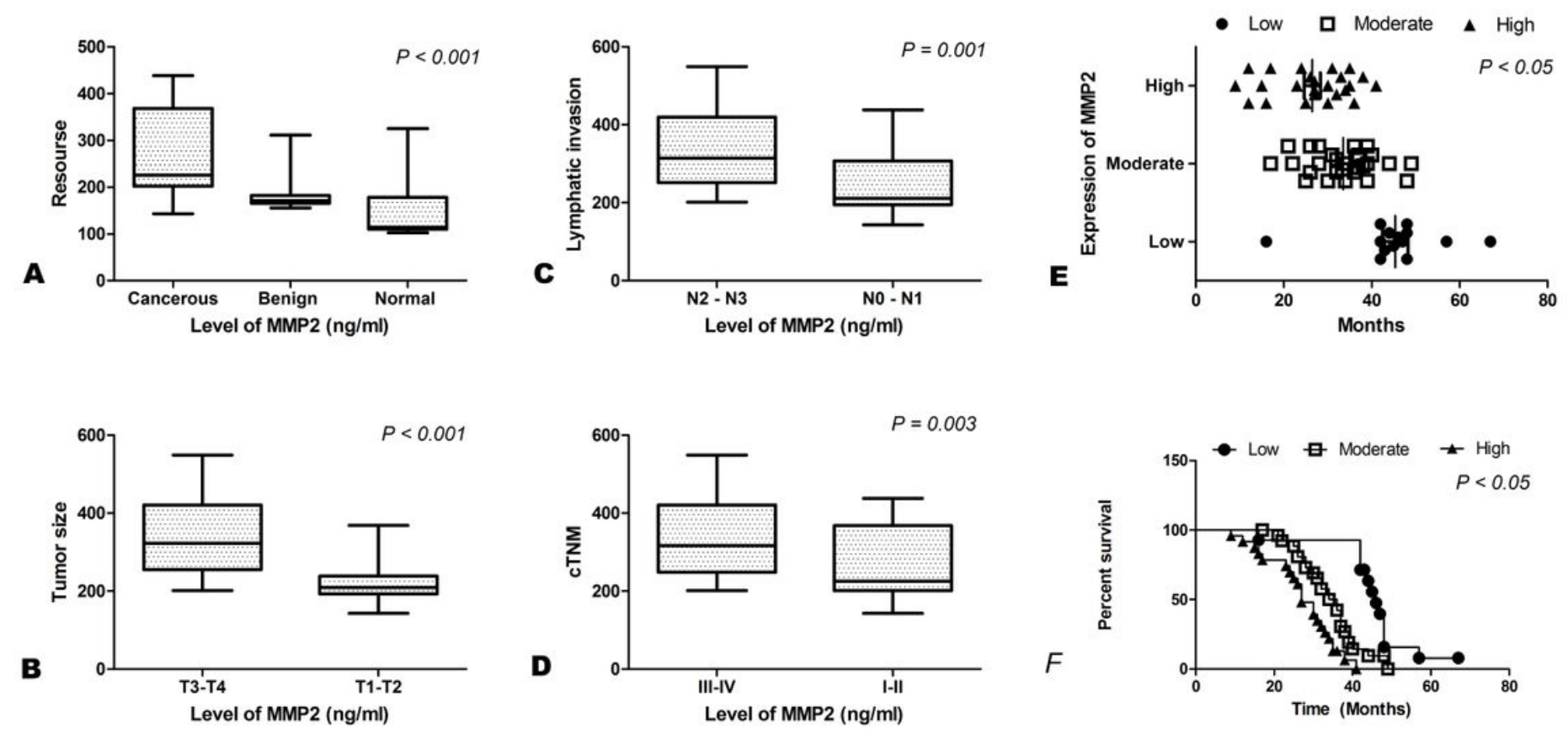

Figure 3

Serum expression of MMP2 in lung cancer, benign lung disease and normal individuals. (A) Increased serum level of MMP2 in lung cancer patients than in patients with benign lung disease patients and healthy people $(p<0.05)$. (B) Higher level of serum MMP2 in lung cancer patients at T3-4 stage was significantly higher than that in T1-2 stage $(p<0.05)$. (C) Lung cancer patients with lymph node metastasis (N2-N3) showed a higher level of serum MMP2 than patients with lymph node metastasis (N0-N1) $(p<0.05)$. (D) Increase of serum MMP2 was displayed in patients with lung cancer at stages III-IV compared with those of stages I-II $(p<0.05)$. SCLC, small cell lung cancer. LAC, lung adenocarcinoma. LSCC, lung squamous cell carcinoma. N, node stage (TNM classification). 

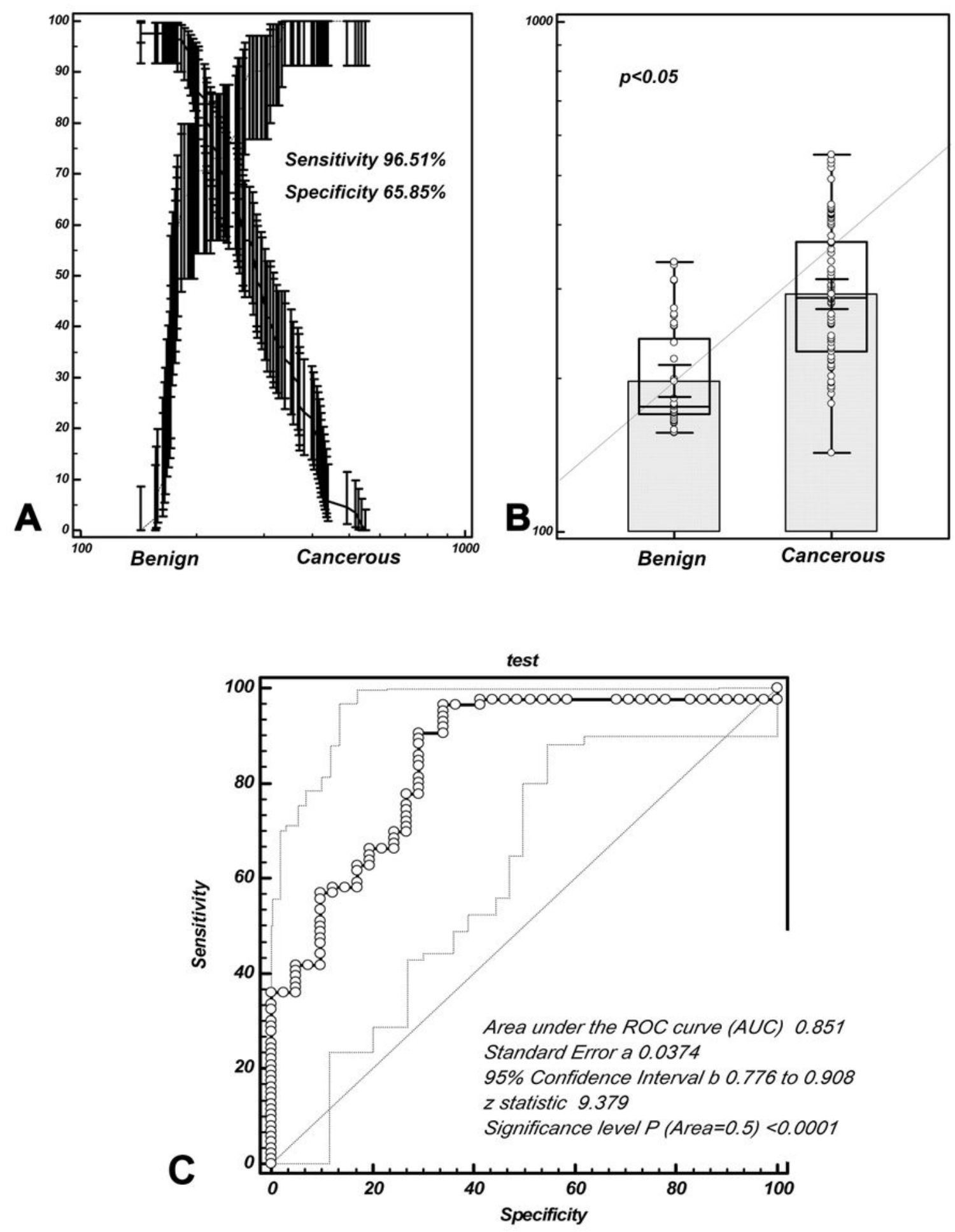

Figure 4

Diagnostic efficacy of serum MMP2 for discerning lung cancer patients from benign lung disease. ( $A$ and B) Selection of critical value $(182.8 \mathrm{ng} / \mathrm{ml})$ of serum MMP2 for discerning lung cancer patients from patients with benign lung disease responded a sensitivity of $96.51 \%$ and specificity of $65.85 \%$. (C) ROC of MMP2 for distinguishing lung cancer patients from patients with benign lung disease (AUC $=0.851)$. ROC, receiver operating characteristic curve; AUC, area under the curve. 

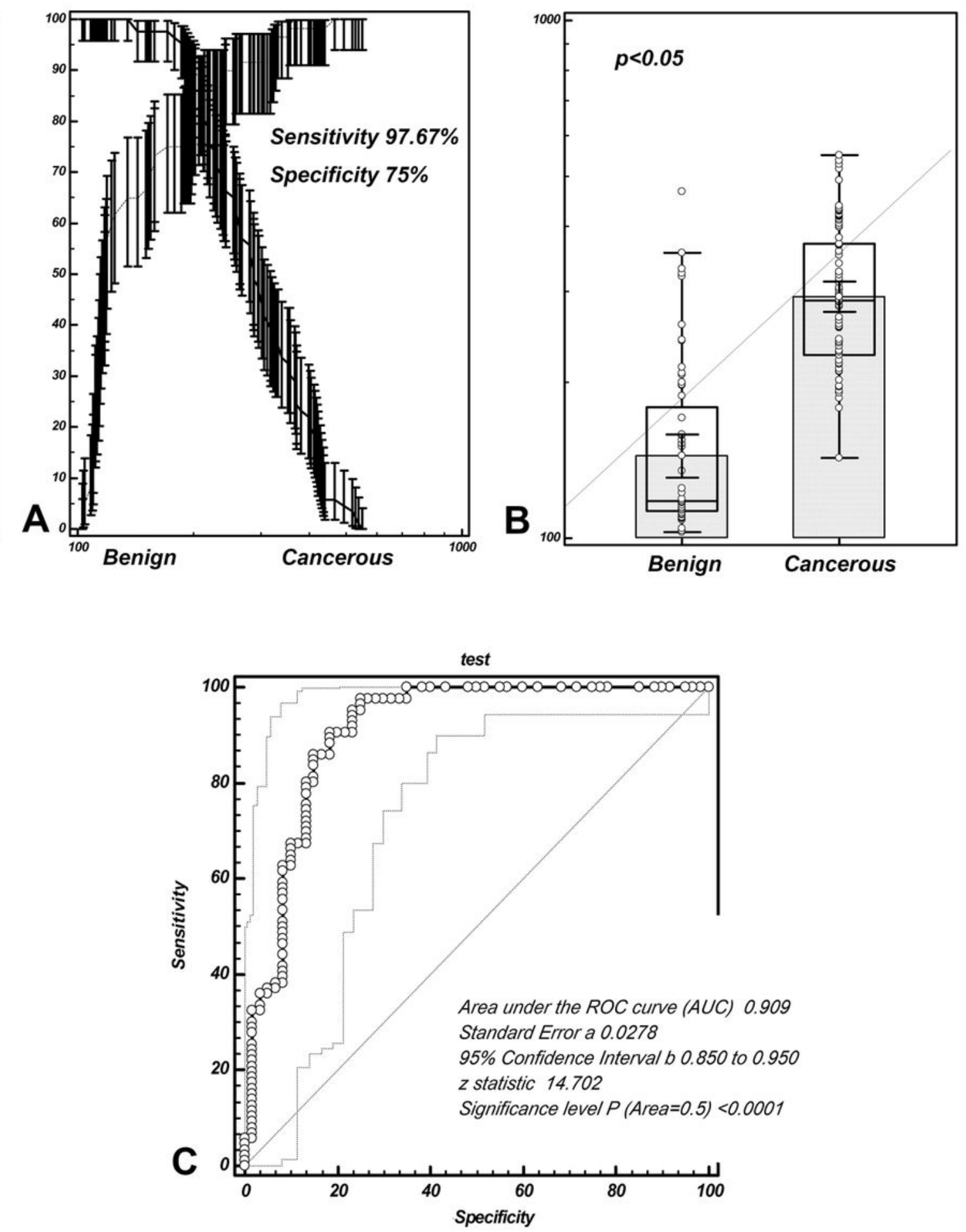

\section{Figure 5}

Diagnostic efficacy of serum MMP2 for lung cancer for discerning lung cancer patients from healthy people. (A and B) Selection of critical value $(170.9 \mathrm{ng} / \mathrm{ml})$ of serum MMP2 for discerning lung cancer patients from healthy people responded a sensitivity of $97.67 \%$ and specificity of $75 \%$. (C) ROC of MMP2 for distinguishing lung cancer patients from healthy people (AUC=0.909); ROC, receiver operating characteristic curve; AUC, area under the curve. 